\title{
New Targets in Pain, Non-Neuronal Cells, and the Role of Palmitoyletha- nolamide
}

\author{
Jan M. Keppel Hesselink*
}

Department of Pharmacology and Toxicology, University of Witten/Herdecke, Germany

\begin{abstract}
Persistent pain in neuropathic conditions is often quite refractory to conventional analgesic therapy, with most patients obtaining, at best, only partial relief of symptoms. The tendency still exists to treat these complex pains with one or a combination of two analgesics at the most. Given the complex nature of the underlying pathogenesis, this approach more often than not fails to produce a meaningful improvement. New targets are therefore badly needed. In this regard non-neuronal cells - glia and mast cells in particular - are emerging as new targets for the treatment of neuropathic pain. An extensive preclinical database exists showing that the naturally occurring fatty acid amide palmitoylethanolamide is endowed with anti-inflammatory activity, and clinical trials assessing the efficacy and safety of palmitoylethanolamide in neuropathic pain have been successful in generating proof-of-concept for treatment in man. Here I will review salient preclinical and clinical evidence supporting non-neuronal cells as viable targets in the treatment of neuropathic pain. This will be followed by a discussion of recent proof-of-concept clinical trials demonstrating the efficacy and safety of palmitoylethanolamide in the treatment of various neuropathic pain states.
\end{abstract}

Keywords: New targets, pain, non-neuronal cells, palmitoylethanolamide.

\section{EMERGENCE OF A MULTI-MODEL THERAPY FOR PAIN}

The pharmacotherapy of pain is evolving from a step-bystep approach to a multimodal therapy which, I believe, is destined to become the hallmark in how we treat neuropathic pain in the future. However, the literature at present provides little guidance on a suitable treatment regimen to follow. Current focus remains on the modulation of functions of the nervous system itself, especially ion channels, without taking other players into consideration - glia, mast cells, and other immune-competent cells. This is unfortunate, as the major players in the pathogenesis of chronic neuropathic pain most probably are these non-neuronal cells. [1-6]

Generally, there is a hierarchy of treatments for neuropathic pain physicians will mostly follow, starting often with monotherapy and increasing to maximal tolerated dose. When high-dose monotherapy proves insufficient or intolerable side effects prevent optimal pain control, combinations of various pharmacologic compounds follow next. The latter may comprise combining serotonin-noradrenaline uptake inhibitors, tricyclic antidepressants, anticonvulsants, opioids, natural and synthetic derivatives from Cannabis, endocannabinoids and topical analgesics. [7-10]

Most clinical studies have been conducted in painful polyneuropathy associated with diabetes, followed by postherpetic neuralgia. Studies in other types of neuropathic pain, such as pain in chronic idiopathic axonal polyneuropa thy, chemotherapy-induced pain and central neuropathic pain

*Address correspondence to this author at the Institute for Neuropathic Pain, Bosch en Duin, the Netherlands; Tel: 0031-6-51700527;

E-mails: jan@neuropathie.nu; info@ores.nl as in stroke and multiple sclerosis (MS) are rare; even more rare are studies in spinal pain syndromes.

\section{THE STATIC NATURE OF ANALGESIC THERA- PEUTIC EFFICACY}

Although our understanding of neuropathic paingenerating mechanisms has advanced considerably since 2000 , there has not been a corresponding improvement in treatment efficacy. Opiates and drugs such as amitriptyline remain unsurpassed as therapeutics.

Finnerup et al., [11] evaluated the 69 randomized controlled trials published in the past 5 years and compared these to the 105 trials published in the preceding 39 years. Their conclusion was intriguing: no real improvement in the treatment of neuropathic pain has been achieved, and recent clinical trials of older analgesics seem even to show an increase in numbers needed to treat $(\mathrm{NNT})^{1}$.

These authors further analyzed all completed clinical trials to date, to identify negative trials and publication bias. In addition to the published trials, their database presented one trial examining gabapentin $3600 \mathrm{mg}$, which relieved painful polyneuropathy with an NNT of $7.0(4.3-20)$, as well as four positive and three negative trials with pregabalin, revealing a combined NNT of $9.5(6.8-16.0)$. The observations imply that the figures most often quoted on NNT's of analgesics are flawed; these analgesics might be even less efficacious than previously thought. This fact, together with

\footnotetext{
${ }^{1}$ The NNT is the average number of patients who need to be treated to prevent one additional bad outcome (i.e. the number of patients that need to be treated for one to benefit compared with a control in a clinical trial).
} 
the relative high numbers needed to harm ${ }^{2}$ makes one working in this field quite humble [12].

It is clear, especially for scientists working in the field of drug targeting, that most, if not nearly all of the current analgesics have one thing in common: targets are most often ion channels or surface receptors of neurons. [13-15] In this regard, non-neuronal cells and nuclear receptors such as peroxisome proliferator-activated receptors (PPARs) have emerged as important targets in a variety of pain states. [4, 5, 16-18] In this short review we will address some aspects in this emerging field related to non-neuronal targets in chronic and neuropathic pain.

\section{NON-NEURONAL CELLS AS NEW TARGETS FOR NEUROPATHIC PAIN}

Today, there is good evidence that the major players in the pathogenesis of chronic neuropathic pain most probably are non-neuronal cells. [1-6] Mast cells, for example, have been the recognized to play a causative role in the development of hyperalgesia following nerve injury, [19] and their pathogenic involvement has also been demonstrated in chronic low back pain, [20] visceral or pelvic pain, [21-25] and migraine. [26-28]. Moreover, mast cell degranulation distinctly activates trigemino-cervical and lumbosacral pain pathways and elicits widespread tactile pain hypersensitivity. [29] Together with glia, and especially microglia that are known to functionally interact with mast cells, [30] these immune cell types are now considered to be key to the phenomena of central and peripheral sensitization. [1-6].

Garrison et al., [31] were the first to demonstrate that after a unilateral ligation of nervous ischiadicus, unilaterally spinal glia became activated, swollen and a new phenotype of activated glia induced. This observation was soon followed by comparable findings in a variety of other studies. $[32,33]$ Peripheral nerve injuries induce a low-grade inflammation in the dorsal horns of spinal cord and along the pain pathways to the thalamus and further to the parietal cortex, [34] due to the activation of Schwann cells, glial cells (especially microglia), and the production of cytokines and other inflammatory mediators within the PNS and CNS. [35-38] Such neuroinflammatory activity leads to the consolidation of the winding up phenomena, the central and peripheral sensitization. [39] Schwann cells, glia, microglia and astrocytes therefore play a central role in the pathogenesis of neuropathic and chronic pain. Gliopathic pain or asteropathic pain might even become new synonyms for neuropathic pain. There are data to support chronic pain syndromes such as rheumatoid arthritis and fibromyalgia as also linked to glia cell activation. [40-43]

Interestingly, also breakthrough pain (i.e., the transient exacerbation of pain experienced by a patient with relatively stable and controlled baseline pain) has been hypothesized to be due, at least in part, to glia hyper-reactivity. [44]

In a recent hallmark paper by Ohara et al., [45] the term 'gliopathic pain' indeed was coined. Glia, astrocytes and other immunocompetent cells directly influence neurotransmission between two neurons, and the recently introduced

\footnotetext{
${ }^{2}$ The number needed to harm (NNH) is similar to NNT and indicates how many patients need to be exposed to a risk factor to cause harm in one patient who would not otherwise have been harmed. The lower the $\mathrm{NNH}$, the worse the risk factor.
}

terminology 'pentapartite synapse' indicates the profound influence of these non-neuronal cells on neurotransmission. $[46,47]$ Glia-modulating drugs will therefore become a new class of analgesics, enhancing our pharmacotherapeutic armamentarium. $[3,44,48,49]$ The first prototype is already available for human use. It is the endogenous fatty acid amide palmitoylethanolamide (PEA), and in more than 20 clinical trials the efficacy and safety of this compound have been documented and will be discussed later in this article. Thus, proof-of-principle (POP) for non-neuronal cells as targets in neuropathic pain has been established. Because many of these clinical studies have been published in Italian or Spanish journals, and the English speaking community might have missed this important new chapter in the treatment of chronic pain, we now focus on the endogenous non-neuronal cell modulator PEA.

\section{PEA - AN ENDOGENOUS ANALGESIC AND MODU- LATOR OF GLIA AND MAST CELLS}

PEA is a naturally occurring fatty acid amide belonging to the class of endocannabinoids which include, among others anandamide, oleoylethanolamide, stearoylethanolamide and lauroylethanolamide.

Amide lipids like PEA are widely distributed in nature, in a variety of plant, invertebrate, and mammalian tissues. [50, 51]

PEA is available in some European countries (Italy, Spain, the Netherlands, and since 2011 also in Germany) for the treatment of chronic pain and chronic inflammation, as a diet food for medical purposes (Normast ${ }^{\mathrm{TM}}$ ). [52]

PEA first attracted attention in 1957, with its isolation from soybeans, peanuts, and egg yolk and identification of anti-inflammatory activity [53]. PEA is produced on demand and accumulates locally during several inflammatory and painful disorders, e.g. intestinal inflammation, [54] chronic migraine, [55] neuropathic pain, $[56,57]$ cerebral ischemia [58] and MS. [59] Increase in PEA local levels is unquestionably considered to play protective and pro-homeostatic roles. [60] PEA exerts anti-inflammatory and antihyperalgesic effects in various animal models of inflammation and pain $[60,61]$ and it has been suggested to function as an endogenous regulator of nociception. [62]

Since the first paper on PEA was indexed in Pumed in 1968 [63] nearly 300 entries have appeared, under the keyword 'palmitoylethanolamide'. In the 1990s the relationship between anandamide and PEA was first described, with growing insight into the function of the endocannabinoids such as oleamide, 2-lineoylglycerol, 2-palmitoylglycerol, and investigation into their capacity to modulate pain sensitivity and inflammation. [64] In the course of these studies it emerged that PEA could alleviate, in a dose-dependent manner, pain behaviors elicited in mouse pain models and downregulate mast cell hyperactivity. $[65,66]$

Mast cells are immunocompetent cells often found in proximity to sensory nerve endings. Their degranulation (i.e. the release of dozens of bioactive mediators stored in intracellular granules) can enhance the nociceptive signal, which is why peripheral mast cells are considered to be proinflammatory and pro-nociceptive. [67] For example, mast cells synthesize, store and release nerve growth factor, [68] 
which itself produces inflammation and sensitization of the peripheral terminals of sensory neurons. [69] Mast cells are found also in the spinal dura, the thalamus and the dura mater. $[67,70]$ Conceivably, PEA may represent a new therapeutic approach for migraine, as meningeal nociceptors can be activated locally through a neuroimmune interaction with resident mast cells populating the dura mater. [27] Human mast cells release a vast array of mediators, which may well account for the mast cell's broad involvement in physiological and pathophysiological functions and diseases. Mast cell modulation by PEA might thus be relevant for disorders such as bladder pain, pelvic, pain, sciatic pain, headache, postsurgical pain, prostate pain and male infertility, chronic regional pain syndrome (CRPS), burning mouth syndrome, and mast cell activation syndrome, among others. [25, 29, 71-80]

Indeed, there are numerous examples of PEA downmodulation of mast cells in vitro and in vivo, resulting in decreased release of various bioactive mediators (i.e., histamine, tumor necrosis factor-alpha, prostaglandins, nerve growth factor, serotonin). [81-84] This, in turn, produced clinical effects such as pain relief and better motor function after spinal cord injury. [66, 84-87]

Furthermore, PEA protects microglial cells from excitotoxicity, [88] Microglia possess the machinery to synthesize and hydrolyze PEA. [89] PEA is able to control the microglial behaviour [58, 90] and revert microglial hyperactivation in the spinal cord during experimental neuropathic pain, suggesting targeted glial effects of PEA in the CNS of chronic pain-affected subjects. [91]

\section{MAIN TARGET OF PEA: PPAR-a}

PEA mechanism(s) of action is still a matter of debate, although it seems that the antinociceptive effect is mediated by multiple mechanisms (i.e., multimodal mechanism of action). [60] Membrane receptors (i.e., cannabinoid receptors), [81] nuclear receptors (i.e. PPAR), [92, 93] neurosteroid synthesis, [94] mast cell down-modulation [82, 86, 87] and control of microglial activation [91] are all purported mechanisms of action of PEA. These may coexist, depending upon the physiological and pathophysiological circumstances. [95]

A separate effect, the so called entourage-effect, has been used to explain PEA biological activities. [96, 97] Although PEA affinity for cannabinoid $\mathrm{CB} 1$ and $\mathrm{CB} 2$ receptors is very low, [98] its antinocicepive effects are prevented by the cannabinoid receptor antagonists. [65, 99] Thus when referring to PEA, it is now preferable to use the term "cannabimimetic compound" or "indirect endocannabinoid" [100].

Although PEA has affinity for other PPAR isoforms, Gcoupled receptors, novel cannabinoid receptors, and receptors GPR55 and GPR119 with an unknown function, [92, 101-103] PPAR- $\alpha$ may be the main biological target of PEA.

PEA up-regulates PPAR- $\alpha$ in a model of spinal cord injury. [87] In this injury model, PPAR- $\alpha$ is down-regulated, resulting in activation of inflammatory cascades leading to tissue destruction. PPAR- $\alpha$ activation by PEA inhibits these detrimental cascades. Delta9-tetrahydrocannabinol also exerts neuroprotective properties, most probably via a PPAR- $\alpha$ mechanism of action. [104] PEA up-regulation of PPAR- $\alpha$ results in decreased output of inflammatory mediators like tumor necrosis factor- $\alpha$ and interleukins, thus supporting PEA's role as a modulator of inflammation and pain. [87] Activation of PPAR- $\alpha$ is neuroprotective and, more generally cytoprotective in a number of animal models. [104-106] PEA also reduces neurological deficits in a spinal trauma model, via reduction of mast cell infiltration and activation. [87]

The concept of lipid N-acylethanolamines such as PEA acting in an autocoid manner to control mast cell activation was first proposed by the Nobel laureate Rita LeviMontalcini in 1993, [107] using the acronym ALIA (Autacoid Local Injury Antagonism). [81,107] Under this nomenclature lipid amides like PEA are classified as ALIAmides, beingautocoids (regulating molecules) locally produced and acting locally. In this sense prostaglandins are also classified as autocoids. In the case of ALIAmide, these autocoids are synthesized in response to injury or inflammation, to counteract such pathology. The period 1993-2011 has seen numerous publications dealing with the modulatory effects of PEA on mast cells. [81-87,108,109]

PEA affinity for PPAR- $\alpha$, coupled with the widespread presence of this receptor in CNS microglia and astrocytes (which play a key role in the winding up phenomena, based on peripheral and central sensitization [110]) provides a strong underlying rationale for PEA application in the treatment of neuropathic pain. [111-114] Further, PEA performed better in the so-called mice forced swimming test compared to the anti-depressant fluoxetine. [115] PEA antiinflammatory action counteracted reactive astrogliosis induced by beta-amyloid peptide in a rodent model relevant for neurodegeneration, most probably via PPAR- $\alpha$. [116] In models of stroke, MS and other CNS trauma settings, PEA displayed neuroprotective properties. [59, 87, 112, 113] At the clinical level, in Italy for example, neurologists have used this preclinical evidence as the impetus to treat patients suffering from a variety of disorders, from MS to neuropathic pain. $[18,61,62,65,66,84-88,92-94,111-113,115]$

\section{PEA: THE CLINICAL PERSPECTIVE}

Clinical research on PEA started in the 1960s and 1970s, especially in the Czech Republic. [117-121] PEA, at that time under the brandname 'Impulsin' was indicated for prevention of flu and respiratory diseases and immune system enhancement. Many years have since passed, with PEA being subsequently explored in a variety of pain states: diabetic neuropathy, carpal tunnel syndrome, dental and temporomandibular joint pain, arthritic, postherpetic and chemotherapy-induced neuropathic pain. Below we will describe data from a number of human clinical pain trials. The main results are outlined in Table $\mathbf{1}$ and have been discussed by Keppel Hesselink. [122] Overall, more than 2000 patients have been successfully treated with PEA, and no adverse effects reported in any of the trials.

\section{Effect of PEA on Central and Peripheral Neuropathic Pain}

A key dosing trial was performed in Italy by Guida and colleagues. [123] These authors carried out a placebocontrolled, double-blind, randomized study on 636 patients suffering from lumbosciatic pain (hernia and nerve root compression), with a mean Visual Analogue Pain Scale 
Table 1. Analgesic Effect of PEA on Chronic Pain: Overview of Clinical Trials.

\begin{tabular}{|c|c|c|c|c|c|}
\hline & Indication \& Trial Design & $\begin{array}{l}\text { Number of } \\
\text { Patients }\end{array}$ & PEA Dosage & Main Results & Ref \\
\hline \multirow{8}{*}{ 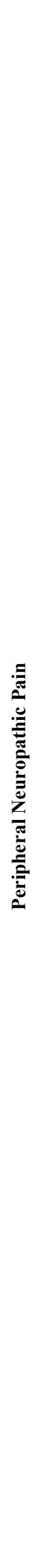 } & $\begin{array}{l}\text { Sciatic pain } \\
\text { Double blind, randomized, two } \\
\text { doses of PEA vs placebo }\end{array}$ & 636 & $\begin{array}{c}1^{\text {st }} \text { arm: } 300 \mathrm{mg} / \mathrm{die} \\
\text { x } 3 \text { weeks } \\
2^{\text {nd }} \text { arm: } 300 \mathrm{mg} / \text { bid for } \\
\text { weeks }\end{array}$ & $\begin{array}{l}\text { Significant decrease of pain on } \\
\text { VAS (from } 7 \text { to 2) }\end{array}$ & [123] \\
\hline & $\begin{array}{l}\text { Pudendal neuralgia } \\
\text { Case Report }\end{array}$ & 1 & $\begin{array}{l}300 \mathrm{mg} / \text { tid gradually de- } \\
\text { creasing to } 300 \mathrm{mg} / \mathrm{die} \\
\text { for1 year }\end{array}$ & Resolution of chronic pelvic pain & [124] \\
\hline & $\begin{array}{l}\text { Postoperative pain (surgical ex- } \\
\text { traction of impacted lower third } \\
\text { molars) } \\
\text { Single-blind, randomized, split- } \\
\text { mouth }\end{array}$ & 30 & $\begin{array}{l}300 \mathrm{mg} / \mathrm{bid} \text { for } 6 \text { days } \\
\text { before and } 9 \text { days after } \\
\text { surgery }\end{array}$ & $\begin{array}{l}\text { Significant reduction in pain inten- } \\
\text { sity }\end{array}$ & [126] \\
\hline & $\begin{array}{l}\text { TMJ pain caused by osteoarthritis } \\
\text { Double blind randomized } v s \\
\text { NSAIDs }\end{array}$ & 24 & $\begin{array}{c}300 \mathrm{mg} \text { at morning }+ \\
600 \mathrm{mg} \text { at evening for } 7 \\
\text { days; followed by } \\
300 \mathrm{mg} / \mathrm{bid} \text { for } 7 \text { days } \\
\text { Vs ibupfofen ( } 600 \mathrm{mg} / \mathrm{tid} \\
\text { for } 14 \text { days) }\end{array}$ & $\begin{array}{l}\text { Significant decrease of pain on } \\
\text { VAS (from } 7 \text { to } 0.7 \text { ) an significant } \\
\text { better maximum mouth opening } \\
\text { compared to ibuprofen. }\end{array}$ & [127] \\
\hline & $\begin{array}{l}\text { Carpal tunnel syndrome in dia- } \\
\text { betic patients } \\
\text { Group-controlled, randomized vs } \\
\text { non-treated patients }\end{array}$ & 40 & $600 \mathrm{mg} / \mathrm{bid}$ for 60 days & $\begin{array}{l}\text { Significant reduction of pain and } \\
\text { functional status. } \\
\text { Significant improvement neuro- } \\
\text { physiologic parameters }\end{array}$ & [132] \\
\hline & $\begin{array}{l}\text { Pain associated with carpal tunnel } \\
\text { syndrome } \\
\text { Group-controlled, randomized, } \\
\text { two doses of PEA vs non-treated } \\
\text { patients }\end{array}$ & 26 & $\begin{array}{c}1^{\text {st }} \text { arm: } 300 \mathrm{mg} / \text { bid for } 30 \\
\text { days } \\
2^{\text {nd }} \text { arm: } 600 \mathrm{mg} / \text { bid for } 30 \\
\text { days }\end{array}$ & $\begin{array}{l}\text { Significant dose-dependent reduc- } \\
\text { tion of pain and improvement of } \\
\text { neurophysiologic parameters com- } \\
\text { pared with control group. }\end{array}$ & [133] \\
\hline & $\begin{array}{l}\text { Neuropathic pain } \\
\text { Open }\end{array}$ & 27 & $\begin{array}{l}300 \mathrm{mg} / \text { bid for } 3 \text { weeks } \\
\text { followed by } \\
300 \mathrm{mg} / \text { die for } 4 \text { weeks }\end{array}$ & $\begin{array}{l}\text { Significant reduction of pain and } \\
\text { improvement of electrophysiologi- } \\
\text { cal parameters }\end{array}$ & [134] \\
\hline & $\begin{array}{l}\text { Low back pain } \\
\text { Open (Combination therapy) }\end{array}$ & 20 & $\begin{array}{l}\text { 600mg/bid for } 30 \text { days } \\
\qquad+ \\
\text { oxycodone (see text for } \\
\text { dosage) }\end{array}$ & $\begin{array}{l}\text { Significant decrease of pain on } \\
\text { VAS (from } 7 \text { to } 2.5 \text { ) }\end{array}$ & [136] \\
\hline
\end{tabular}


Table 1. Contd....

\begin{tabular}{|c|c|c|c|c|c|}
\hline & Indication \& Trial Design & $\begin{array}{l}\text { Number of } \\
\text { Patients }\end{array}$ & PEA Dosage & Main Results & Ref \\
\hline & $\begin{array}{l}\text { Neuropathic chronic pain (Dia- } \\
\text { betic neuropathy and postherpetic } \\
\text { neuralgia) } \\
\text { Open (Combination therapy) }\end{array}$ & 30 & $\begin{array}{c}\text { Combination of Pre- } \\
\text { gabalin+PEA 600mg bid } \\
\text { for } 45 \text { days } \\
+ \\
\text { pregabalin (see text for } \\
\text { dosage) }\end{array}$ & $\begin{array}{l}\text { Significant decrease of pain on } \\
\text { VAS, from } 7.6 \text { to } 1.8\end{array}$ & [137] \\
\hline & $\begin{array}{l}\text { Various pain states (see text) } \\
\text { Open (Combination therapy) }\end{array}$ & 517 & $\begin{array}{c}600 \mathrm{mg} / \text { bid for } 3 \text { weeks } \\
\text { followed by } 600 \mathrm{mg} / \mathrm{die} \\
\text { for } 4 \text { weeks } \\
+ \\
\text { Pregabalin and oxycodone } \\
\text { (see text) }\end{array}$ & $\begin{array}{l}61 \% \text { decrease of mean pain score on } \\
\text { Numeric Rating Scale }\end{array}$ & [138] \\
\hline & $\begin{array}{l}\text { Diabetic neuropathic pain } \\
\text { Group- controlled: Combination } \\
\text { of PEA }+ \text { Pregabalin vs Pre- } \\
\text { gabalin }\end{array}$ & 74 & $\begin{array}{l}600 \mathrm{mg} / \text { bid for } 10 \text { days } \\
\text { followed by } \\
600 \mathrm{mg} / \text { die for } 20 \text { days } \\
\text { followed by } \\
300 \mathrm{mg} / \text { die for } 30 \text { days }\end{array}$ & $\begin{array}{l}\text { Significantly higher rate of re- } \\
\text { sponders (i.e., }<60 \% \text { decrease in } \\
\text { pain score) in the combination } \\
\text { therapy group compared to pre- } \\
\text { gabalin only group. }\end{array}$ & [140] \\
\hline 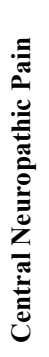 & $\begin{array}{l}\text { Neuropathic pain associated with } \\
\text { multiple sclerosis } \\
\text { Open }\end{array}$ & 20 & $300 \mathrm{mg} / \mathrm{bid}$ for 60 days & $\begin{array}{l}\text { Significant decrease of neuropathic } \\
\text { pain }\end{array}$ & [129] \\
\hline \multirow{3}{*}{ 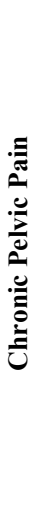 } & $\begin{array}{l}\text { Chronic pelvic pain associated } \\
\text { with endometriosis/ dysmenor- } \\
\text { rhoea /interstitial cystitis } \\
\text { Open }\end{array}$ & 25 & $\begin{array}{l}200 \mathrm{mg} / \mathrm{tid}(+ \text { polydatin } \\
20 \mathrm{mg} / \mathrm{tid}) \text { for } 40 \text { days }\end{array}$ & $\begin{array}{l}\text { Significant reduction of pain on } \\
\text { VAS (from } 6.8 \text { to } 1.7 \text { ). } \\
\text { Significant decrease in the use of } \\
\text { NSAIDs. }\end{array}$ & [143] \\
\hline & $\begin{array}{l}\text { Adolescent primary dysmenor- } \\
\text { rhoea } \\
\text { Open }\end{array}$ & 20 & $\begin{array}{c}400 \mathrm{mg} / \mathrm{bid}(+ \text { polydatin } \\
40 \mathrm{mg} / \mathrm{bid}) \\
\text { for } 6 \text { months }\end{array}$ & $70 \%$ decrease of pelvic pain & [144] \\
\hline & $\begin{array}{l}\text { Chronic pelvic pain and dyspare- } \\
\text { unia associated with endometri- } \\
\text { osis } \\
\text { Open (case series) }\end{array}$ & 4 & $\begin{array}{l}200 \mathrm{mg} / \mathrm{bid}(+ \text { polydatin } \\
20 \mathrm{mg} / \mathrm{bid}) \text { for } 3 \text { months }\end{array}$ & $\begin{array}{l}\text { Significant decrease of pelvic pain. } \\
\text { Significant decrease of dyspareunia. } \\
\text { Significant reduction in the use of } \\
\text { analgesics. }\end{array}$ & [145] \\
\hline
\end{tabular}


Table 1. Contd....

\begin{tabular}{|c|c|c|c|c|}
\hline Indication \& Trial Design & $\begin{array}{l}\text { Number of } \\
\text { Patients }\end{array}$ & PEA Dosage & Main Results & Ref \\
\hline $\begin{array}{l}\text { Chronic pelvic pain associated } \\
\text { with endometriosis } \\
\text { Double blind, ,randomized paral- } \\
\text { lel-group, placebo-controlled }\end{array}$ & 61 & $\begin{array}{c}400 \mathrm{mg} / \mathrm{tid}(+40 \mathrm{mg} / \mathrm{tid} \\
\text { polydatin) for } \\
3 \mathrm{months} \\
\mathrm{Vs} \\
\text { celecoxib } 200 \mathrm{mg} / \mathrm{bid} \text { for } \\
7 \text { consecutive days }\end{array}$ & $\begin{array}{l}\text { Significant decrease of cronic pelvic } \\
\text { pain, dysmenorrhoea and dyspare- } \\
\text { unia in the PEA group compared to } \\
\text { placebo group }\end{array}$ & [146] \\
\hline
\end{tabular}

Abbreviations: bid, bis in die = twice daily; die, daily; NSAIDs, non-steroidal anti-inflammatory drugs; tid, ter in die = three times daily; TMJ, temporomandibular joint; VAS, visual analogue pain scale..

(VAS) pain score at baseline of 6.5. The study consisted of three arms: placebo, PEA $300 \mathrm{mg} /$ day and PEA $600 \mathrm{mg} /$ day. The results after 3 weeks of treatment: placebo, decrease of pain from mean VAS 6.5 to mean VAS 4.5 ; $300 \mathrm{mg}$ PEA, 6.5 to $3.5 ; 600 \mathrm{mg}$ PEA, 7.1 to VAS 2.1. PEA at the lower dose (300 mg) was significantly better compared to placebo, and higher dose PEA (600 mg) was significantly better compared both to the lower dose and to placebo. No relevant adverse events were reported. In the Youtube and Prezi added to this paper, further details on study outcome are presented and discussed.

Interestingly, a case report on a 40 -year-old healthy man with pudendal neuralgia (probably secondary to nerve compression) was recently published. The patient, who originally rated his pain at 8 on the $0-10$ VAS, experienced a significant improvement of neuralgia and associated symptoms on PEA, up to $900 \mathrm{mg} /$ day. [124]

The results of an open study performed on 30 patients suffering from diabetic neuropathy were recently presented at the 2011 Congress of the European Shock Society. [125] Orally administered PEA (300 mg/twice daily for 60 days) significantly reduced the clinical sensory symptoms $(\mathrm{p}<0.001)$, as scored by the Michigan Neuropathy Screening Instrument, Total Symptom Score, and Neuropathic Pain Symptom Inventory. In particular, PEA treatment significantly reduced the severity and frequency of pain, burning, paraesthesia and numbness. Moreover, the study clearly demonstrated that the analgesic effect manifested itself as early as 30 days after treatment start, progressively increased over time and was maintained 1 month after treatment discontinuation [125].

PEA reduced pain after surgical extraction of impacted lower third molars. A randomized, split-mouth, single-blind study was conducted on 30 patients between 18 and 30 years of age requiring lower third molar extraction. Patients underwent bilateral extractions in a randomized sequence, with one extraction being performed under PEA treatment (300 $\mathrm{mg} /$ twice daily for 15 days). Perceived postoperative pain, as measured on VAS, was significantly lower with PEA treatment compared to control $(\mathrm{p}<0.05)$ [126].

PEA was beneficial in osteoarthritic (OA) pain (which is considered a mixed pain, i.e., nociceptive and neuropathic components together) where it performed significantly better than a classical non-steroidal anti-inflammatory drug. In this study a double-blind, randomized group-controlled trial was performed on 24 patients suffering from temporomandibular joint OA and divided in two groups: one $(n=12)$ treated with PEA (300 mg in the morning plus $600 \mathrm{mg}$ in the evening for 7 days, followed by $300 \mathrm{mg} /$ twice daily for 7 more days); the second $(n=12)$ received ibuprofen $(600 \mathrm{mg} /$ three times daily for two weeks). Spontaneous pain (on VAS) and maximum mouth opening were recorded and both resulted significantly better in the PEA-treated group compared to the ibuprofengroup [127].

Twenty post-stroke patients, suffering from pain and limb spasticity (i.e., hemiparesis, hemiplagia, paraparesis) received either rehabilitation alone, or rehabilitation therapy and PEA $(600 \mathrm{mg} / \mathrm{twice}$ daily for 8 weeks, followed by 600 $\mathrm{mg} / \mathrm{sid}$ for 4 adjunctive weeks). The results of this blind, randomized, group-controlled study revealed that PEA treatment not only reduced pain intensity (as measured by means of VAS) but also decreased spasticity as measured by a modified Ashworth scale. The difference between the two treatment groups were statistically significant $(\mathrm{p}<0.0006)$. No side effects were reported [128].

A further study on the effect of PEA on central neuropathic pain was performed on 20 patients (age 38-75 yrs) suffering from MS and presenting neuropathic pain of the lower limbs, characterized by dysaesthesia along with allodynia, paraesthesia, cramping pain and burning feet. Pain severity was evaluated by means VAS and was significantly reduced in 14 out of 20 patients $(p=0.001)$ after 2 monthtreatment with PEA $600 \mathrm{mg} /$ day [129].

Lastly, it is interesting to note that in an open observational study, performed on 8 patients with facial postherpetic neuralgia, a topical preparation containing PEA (twice daily applications to the affected site for two to four weeks) successfully controlled postherpetic pain. Five patients $(62.5 \%)$ experienced a mean pain reduction on VAS of $87.8 \%$. The therapy was well-tolerated by all patients, with no unpleasant sensations or adverse events [130].

\section{Effect of PEA on Electrophysiologic Changes in neuro- pathic Patients}

In addition to clinical signs (i.e., pain, spasticity) also electrophysiologic deficits improved under PEA treatment. A group-controlled, randomized study was performed in 50 diabetic patients suffering from carpal tunnel syndrome with moderate pain [131]. The control group (standard care, $\mathrm{n}=25$ ) was tested against PEA (600 mg/twice daily, $\mathrm{n}=25)$. A 
significant improvement in pain at endpoint in the PEAtreated group compared to the control group was noted $(\mathrm{p}<$ $0.0001)$. Moreover, the neurophysiologic parameters assessed (sensory conduction velocity and nerve distal motor latency) improved with PEA treatment. No relevant sideeffects were documented.

In a more recent study from the same group [132], 40 diabetic patients with mild-to-moderate carpal tunnel syndrome were treated orally with PEA $(600 \mathrm{mg} / \mathrm{twice}$ daily for 2 months). These patients presented a significantly decreased pain severity, self-reported symptom severity and functional status (the Boston Carpal Tunnel Questionnaire) and electrophysiologic parameters, as early as 1 month after the beginning of PEA treatment.

A further randomized, group-controlled study on patients with carpal tunnel syndrome and clear neurophysiologic abnormalities and pain was performed with a three-arm design: control (no treatment during the study period, $n=12$ ), PEA (300 mg/twice daily, $\mathrm{n}=6$ ), PEA $300 \mathrm{mg} /$ four times daily $(n=8)$. There was a significant improvement in neurophysiologic parameters (distal motor latency) in both dose arms, with the higher dose being more effective [133]. Further, there was a clinically relevant decrease in pain and fewer signs of Tinel in treatment groups 30 days on. No relevant side-effects were noted [133].

In a preliminary open study on 27 patients with painful neuropathy who were either drug naïve or non-responders to other drugs, PEA $(300 \mathrm{mg} /$ twice daily for 3 weeks, followed by $300 \mathrm{mg}$ /daily for 4 weeks) appeared improve nerve function and reduce neuropathic pain. In this study pain was evaluated on an 11-point numerical rating scale, while nerve function was assessed by nerve conduction (for nonnociceptive fibres) or laser evoked potentials (for nociceptive fibres). PEA treatment increased the amplitude of sural and ulnar sensory nerve action potentials, and decreased the mean pain score. After treatment, the sensory index (i.e., the mean value of the afferent pathway-related neural responses) was higher compared to that at baseline. All results reached statistical significance $(\mathrm{p}<0.05)$ [134].

Finally, this same group of investigators assessed the effect of PEA on pain and nerve function in patients with chemotherapy-induced painful neuropathy [135]. Twenty patients underwent thalidomide (50-200 $\mathrm{mg}$ daily) and bortezomib $(1.3 \mathrm{mg} / \mathrm{m} 2$ twice a week) treatment for Kahler's disease (multiple myeloma). Chemotherapeutic agentinduced neurotoxicity, evidenced as neuropathic pain development and nerve function decline, occurred during the first 3 months. Treatment with PEA (300 mg/twice daily) was carried out between months 3-5. Patients entering the study all suffered from neuropathic pain, and scored at least 4 on Bouhassira's DN4 screening tool for neuropathic pain. All patients were evaluated before and after the two-month treatment with PEA. Parameters measured by blinded observers were: (i) pain and warmth thresholds; (ii) motor and sensory nerve fibre function; (iii) laser-evoked potentials.

Nerve conduction studies consisted of sensory nerve action potentials from sural and ulnar nerves, as well as compound motor action potentials from peroneal and ulnar nerves.
Pain as measured on the VAS decreased from $4.5 \pm 1.2$ to $3.4 \pm 1.0$. All neurophysiologic measures-assessing $\mathrm{A} \alpha, \mathrm{A} \beta$, and $A \delta$ fibre functionality significantly improved compared to baseline, while all patient continued their bortezomib/thalidomide therapy $(\mathrm{P}<0.05)$. None of the variables, however, returned to normal. Had the patients not been treated, nerve function would have deteriorated further and pain increased, making it necessary to stop or reduce chemotherapy.

Although a placebo effect might play a role in the reduction of pain-intensity, the changes in neurophysiologic measures indicate that PEA exerted a neuroprotective effect on myelinated nerve fibers. Without dose-reduction of chemotherapy one would not expect an improvement between months 3 and 5. On the contrary, further deterioration would be expected.[135] The authors concluded: “ PEA, possibly by moderating mast cell hyperactivity, relieved conduction blocks secondary to endoneural edema. In a severe condition such as painful neuropathy associated with multiple myeloma and chemotherapy, a safe substance such as PEA provides significant restoration of nerve function"[135].

\section{PEA May Synergize with Classical Analgesic Drugs}

A number of clinical trials have described a synergistic action between PEA and other analgesics, e.g. opiates and antiepileptic drugs used for neuropathic pain. The first example is the report by Desio, [136] who conducted an open study in 20 patients suffering from chronic pain and unresponsive to a variety of analgesics. In particular, patients suffered from low back pain secondary to collapsed vertebrae, lumbar spinal stenosis syndrome and slipped discs. Treatment regime was as follows: oxycodone daily $(5 \mathrm{mg})$ for 5 days, followed by $5 \mathrm{mg} /$ twice daily for 25 days; in addition, PEA (600 mg) was given twice daily for 30 days. Pain score decreased from a mean of VAS 7 at entry to mean VAS 2.5 at day $30(p<0.001)$. Moreover, pain was observed to decrease as early as the $10^{\text {th }}$ day of treatment, and was maximally reduced at the end of treatment (day 30). No adverse events and no drug-drug interactions were observed.

In a further trial by the same author, PEA was successfully associated to pregabalin in a 45-day treatment of 30 patients suffering from chronic pain due to diabetic neuropathy or postherpetic neuralgia. [137] The treatment regimen was as follows: PEA (600 mg/twice daily) for the whole study duration, associated with pregabalin $75 \mathrm{mg} /$ twice daily for 10 days, followed by a daily dose of $75 \mathrm{mg}$ in the morning plus $150 \mathrm{mg}$ in the evening for the next 10 days; then $150 \mathrm{mg} /$ twice daily for a further 10 days, and finally 200 $\mathrm{mg} / \mathrm{twice}$ daily for the remaining 15 days. The severity of pain, as measured using VAS, significantly decreased during the duration of the study (45 days), from 7.9 to 1.8 $(\mathrm{p}<0.0001)$.

A preliminary report on chronic pain due to different conditions also showed that patients benefited from PEA as an adjunct to classical analgesic drugs. The study was performed on 517 patients, suffering from radiculopathy and/or osteoarthritis $(64.6 \%)$, failed back surgery syndrome $(12.77 \%)$, postherpetic neuralgia (5.8\%), diabetic neuropathy $(4.64 \%)$, oncologic pain $(3.29 \%)$, or other pain states (e.g., trigeminal neuralgia, post-traumatic neuropathy; 8.9\%). PEA (600 mg/twice daily for 21 days followed by $600 \mathrm{mg} /$ day for 
a further 30 days) was added to a fixed dose of pregabalin and oxycodone hydrochloride. Pain was scored at the beginning and end of treatment (51 days) by means of a Numeric Rating Scale. A $61.1 \%$ mean decrease of pain was recorded [138].

The efficacy of PEA as part of a multimodal analgesic therapy in patients with low back pain was presented at the Naples Pain Conference in 2010 [139]. Eighty-one patients were divided in two groups: the first group $(n=41)$ received PEA $(600 \mathrm{mg} /$ twice daily for 21 days followed by 600 $\mathrm{mg}$ /day for the remaining 30 days) on top of standard analgesics (pregabalin, gabapentin, amitriptyline, duloxetine); the second group received standard analgesics only. At day 51 (endpoint) PEA-treated patients had less pain compared to standard care $(\mathrm{p}<0.05)$. No side effects or drug-drug interactions were observed.

More recently, data on the synergism of PEA combined with pregabalin were presented at the $34^{\text {th }}$ AISD Congress by Adiletta and coworkers [140]. The authors performed an open study on 74 patients suffering from diabetic neuropathic pain divided in two groups: pregabalin monotherapy (titrated up to $600 \mathrm{mg} /$ day) or pregabalin with added PEA at a decreasing dose from $600 \mathrm{mg} /$ twice daily to $300 \mathrm{mg} /$ day. Pain severity was evaluated by means of Brief Pain Inventory; the response to treatment was considered to be at least a $60 \%$ decrease in pain score. There was a significantly higher rate of response to pregabalin plus PEA compared to pregabalin only $(73 \%$ responders versus $40 \%) \mathrm{p}<0.01$. No side effects or interactions were observed. [140]

In a group-controlled, randomized study performed on 85 patients suffering from lumbosciatic pain, a 30-day treatment associating PEA (600 mg/day) to standard analgesic therapy was statistically better in relieving pain than the same duration treatment with analgesics alone. This was true for pain evaluations with either VAS or the Oswestry Low Back Pain Scale [141].

Lastly, a randomized, double-blind study, performed using the same design and dose regimen as Guida and collaborators [123] showed a statistically significant decrease $(\mathrm{p}<0.05)$ in the duration of treatment with anti-inflammatory and/or analgesic drugs in the PEA-treated group compared to the placebo group [142].

Overall, these results suggest that PEA may exert a sparing effect on drugs classically used in chronic pain management.

\section{Effect of PEA on Visceral Pain}

The results presented so far clearly illustrate that PEA benefits somatic pain, from neuropathic to postoperative and mixed pain. Interestingly, also chronic pelvic pain, i.e. visceral pain, has been shown to respond to PEA. In particular, when combined with polydatin (i.e. the natural glucoside of resveratrol with anti-inflammatory and antioxidant effects), in the ratio 10:1, PEA exerted an important relief of pelvic pain.

In an open study of 25 female patients suffering from endometriosis $(n=15)$, interstitial cystitis $(n=6)$ and dysmenorrhea $(n=4)$ a 60 day-treatment with PEA $(200 \mathrm{mg} / 3$ times a day) plus polydatin $(20 \mathrm{mg} / 3$ times a day) resulted in a significant decrease of pain, with a VAS score reduction from 6.8 (before treatment) to 3.2 (after 30 days) and 1.7 (after 60 days - study end). Moreover, the combined use of non-steroidal anti-inflammatory drugs significantly decreased [143].

A further preliminary study on the effect of PEA on dysmenorrhea was presented at the Pediatric and Adolescent Gynecology Congress 2010 [144]. Twenty adolescent girls were found to benefit from PEA + polydatin treatment, with a $70 \%$ reduction of dysmenorrhea after a 6-month treatment (PEA $200 \mathrm{mg}+$ polydatin $20 \mathrm{mg} / 3$ times a day).

A case series on chronic pelvic pain successfully treated with PEA was recently published. Four patients presenting a endometriosis-related pain intensity $>5$ on VAS were enrolled and monitored during 3 months of the following treatment: oral PEA $(200 \mathrm{mg})$ and polydatin $(20 \mathrm{mg})$, twice daily for 90 days. Chronic pelvic pain intensity due to endometriosis and deep dyspareunia, dyschezia, dysuria or dysmenorrhoea was evaluated on VAS at baseline and during the programmed follow-up after 1, 2 and 3 months of treatment. All patients experienced pain relief as early as 1 month after starting treatment $(\mathrm{p}<0.0069)$. For dyspareunia there was a significant reduction at day 30 , which remained constant until the end of the study $(\mathrm{p}<0.0132)$. The reduction in pain intensity was paralleled by a statistically significant $(\mathrm{p}<$ 0.0176 ) reduction in analgesics use [145].

In a randomized, double-blind, parallel-group, placebocontrolled clinical trial on 61subjects with endometriosis, patients were submitted to a first line laparoscopic conservative surgery and randomized into 3 groups: group A $(n=21)$ PEA (400 mg) +polydatin (40 mg) twice daily for 3 months; group $B(n=20)$ placebo for 3 months; group $C(n=20)$ a single course of Celecoxib $200 \mathrm{mg}$ twice daily for 7 consecutive days. A marked decrease in dysmenorrhoea, dyspareunia and pelvic pain was observed, with the combination of PEA and polydatin significantly more effective than placebo $(\mathrm{p}<$ $0.001)$. The authors stated that "this safe association shows an optimal control of pain and could be used in patients who are unable to receive other therapies" [146].

\section{DOSE RECOMMENDATIONS OF PEA}

The results of clinical trials with PEA in human pain states, together with current preclinical data suggest that PEA might possess neuro-regenerative properties [147]. PEA is available for clinical use and is marketed by the Italian company Epitech under the trade name Normast ${ }^{\circledR}$ (for neuropathic pain) and Pelvilen ${ }^{\circledR}$ (for pelvic pain) [52]. Two different formulations have been developed, an ultramicronized formulation of PEA for sublingual use, containing $600 \mathrm{mg}$, and tablets of 300 or $600 \mathrm{mg}$ PEA. Combination of PEA with opioids, gabapentoids and antidepressants for treating chronic and neuropathic pain is possible, and no drug-drug interactions have been reported. [148] Synergistic effects of PEA with pregabaline and oxycodone have been described, as discussed above. [136-142]

Based on our knowledge to date, recommended starting treatment dose for PEA is: twice daily $600 \mathrm{mg}$ ultramicronized PEA, in $600 \mathrm{mg}$ sublingual sachets, 10 days or, in the case of central neuropathic pain 20-30 days. After the initial loading dose phase, patients can be treated with 600 $\mathrm{mg}$ tablets twice daily. If pain is reduced at least $30-50 \%$, a lower dose can be selected, i.e., $300 \mathrm{mg} /$ twice daily. In the 
case of a relapse under tablet regime, transfer patients to 600 mg Normast sublingual sachets for at least 20 days. Some patients, especially those with central neuropathic pain may respond better to sublingual sachets, but relapse on tablets.

Physicians wishing to consult the author can do so by sending an email to: jan@neuropathie.nu

An English presentation on this topic for Italian pain specialists, presented at the 2011 congress of 'La società italiana di anestesia analgesia rianimazione e terapia intensiva (SIAARTI) can be found (following a 1.5 minute introduction in Italian) on: http://www.youtube.com $/$ watch? $\mathrm{v}=3$ wgdwcijCt0

Illustration for this article as a Prezi:

http://prezi.com/zgzjdoudele-/glia-modulator-is-breakthroughin-treatment-chronic-and-neuropathic-pain/

\section{CONFLICT OF INTEREST}

None declared.

\section{ACKNOWLEDGEMENT}

None declared.

\section{REFERENCES}

[1] Wen YR, Tan PH, Cheng JK, et al. Microglia: a promising target for treating neuropathic and postoperative pain, and morphine tolerance. J Formos Med Assoc 2011; 110: 487-94.

[2] Nakagawa T, Kaneko S. Spinal astrocytes as therapeutic targets for pathological pain. J Pharmacol Sci 2010; 114: 347-53.

[3] McMahon SB, Cafferty WB, Marchand F. Immune and glial cell factors as pain mediators and modulators. Exp Neurol 2005; 192(2): 444-62.

[4] Ren K, Dubner R. Interactions between the immune and nervous systems in pain. Nat Med 2010; 16(11): 1267-76.

[5] Chiang CY, Dostrovsky JO, Iwata K, et al. Role of glia in orofacial pain. Neuroscientist 2011; 17: 303-20.

[6] Thacker MA, Clark AK, Marchand F, et al. Pathophysiology of peripheral neuropathic pain: immune cells and molecules. Anesth Analg 2007; 105(3): 838-47.

[7] Vorobeychik Y, Gordin V, Mao J, et al. Combination therapy for neuropathic pain: a review of current evidence. CNS Drugs 2011; 25: 1023-34.

[8] Thaler A, Gupta A, Cohen SP. Cannabinoids for pain management. Adv Psychosom Med 2011; 30: 125-38.

[9] Jaggi AS, Singh N. Therapeutic targets for the management of peripheral nerve injury-induced neuropathic pain. CNS Neurol Disord Drug Targets 2011; 10: 589-609.

[10] Kopsky DJ, Keppel HJM. High doses of topical amitriptyline in neuropathic pain: two cases and literature review. Pain Pract 2011; 12(2): 148-53.

[11] Finnerup NB, Sindrup SH, Jensen TS. The evidence for pharmacological treatment of neuropathic pain. Pain 2010; 150: 573-81.

[12] Saarto T, Wiffen PJ. Antidepressants for neuropathic pain. Cochrane Database Syst Rev 2007; 4: CD005454.

[13] Walsh KB. Targeting GIRK Channels for the Development of New Therapeutic Agents. Front Pharmacol 2011; 2: 64.

[14] Estacion M, Waxman SG, Dib-Hajj SD. Effects of ranolazine on wild-type and mutant hNav1.7 channels and on DRG neuron excitability. Mol Pain 2010; 8: 6-35.

[15] Momin A, Wood JN. Sensory neuron voltage-gated sodium channels as analgesic drug targets. Curr Opin Neurobiol 2008; 18: 3838 .

[16] Jasmin L, Vit JP, Bhargava A, Ohara PT. Can satellite glial cells be therapeutic targets for pain control? Neuron Glia Biol 2010; 6: 6371.

[17] Park SW, Yi JH, Miranpuri G, Satriotomo I, et al. Thiazolidinedione class of peroxisome proliferator-activated receptor gamma agonists prevents neuronal damage, motor dysfunction, myelin loss, neuropathic pain, and inflammation after spinal cord injury in adult rats. J Pharmacol Exp Ther 2007; 320: 1002-12.
[18] Raso GM, Esposito E, Vitiello S, et al. Palmitoylethanolamide stimulation induces allopregnanolone synthesis in C6 Cells and primary astrocytes: involvement of peroxisome-proliferator activated receptor- $\alpha$. J Neuroendocrinol 2011; 23: 591-600.

[19] Zuo Y, Perkins NM, Tracey DJ, et al. Inflammation and hyperalgesia induced by nerve injury in the rat: a key role of mast cells. Pain 2003; 105(3): 467-79.

[20] Freemont AJ, Jeziorska M, Hoyland JA, et al. Mast cells in the pathogenesis of chronic back pain: a hypothesis. J Pathol 2002; 197(3): 281-5.

[21] Rudick CN, Bryce PJ, Guichelaar LA, et al. Mast cell-derived histamine mediates cystitis pain. PLoS One 2008; 3(5): e2096.

[22] Barbara G, Stanghellini V, De Giorgio R, et al. Activated mast cells in proximity to colonic nerves correlate with abdominal pain in irritable bowel syndrome. Gastroenterology 2004; 126(3): 693702 .

[23] Hoogerwerf WA, Gondesen K, Xiao SY, et al. The role of mast cells in the pathogenesis of pain in chronic pancreatitis. BMC Gastroenterol 2005; 5(1): 8 .

[24] Anaf V, Chapron C, El Nakadi I, et al. Pain, mast cells, and nerves in peritoneal, ovarian, and deep infiltrating endometriosis. Fertil Steril 2006; 86(5): 1336-43.

[25] Wood JD. Visceral pain: spinal afferents, enteric mast cells, enteric nervous system and stress. Curr Pharm Des 2011; 17(16): 1573-5.

[26] Ba'albaki H, Rapoport A. Mast cells activate the renin angiotensin system and contribute to migraine: a hypothesis. Headache 2008; 48(10): 1499-505.

[27] Levy D, Burstein R, Kainz V, et al. Mast cell degranulation activates a pain pathway underlying migraine headache. Pain 2007; 130(1-2): 166-76.

[28] Levy D. Migraine pain, meningeal inflammation, and mast cells. Curr Pain Headache Rep 2009; 13(3): 237-40.

[29] Levy D, Kainz V, Burstein R, et al. Mast cell degranulation distinctly activates trigemino-cervical and lumbosacral pain pathways and elicits widespread tactile pain hypersensitivity. Brain Behav Immun 2012; 26(2): 311-7.

[30] Yuan H, Zhu X, Zhou S, et al. Role of mast cell activation in inducing microglial cells to release neurotrophin. J Neurosci Res 2010; 88(6): 1348-54.

[31] Garrison CJ, Dougherty PM, Kajander KC, et al. Staining of glial fibrillary acidic protein (GFAP) in lumbar spinal cord increases following a sciatic nerve constriction injury. Brain Res 1991; 22: 1-7.

[32] Meller ST, Dykstra C, Grzybycki D, et al. The possible role of glia in nociceptive processing and hyperalgesia in the spinal cord of the rat. Neuropharmacology 1994; 33(11): 1471-8.

[33] Wagner R, Myers RR. Schwann cells produce tumor necrosis factor alpha: expression in injured and non-injured nerves. Neuroscience 1996; 73: 625-9.

[34] Saadé NE, Jabbur SJ. Nociceptive behavior in animal models for peripheral neuropathy: spinal and supraspinal mechanisms. Prog Neurobiol 2008; 86: 22-47.

[35] Myers RR, Shubayev VI. The ology of neuropathy: an integrative review of the role of neuroinflammation and TNF- $\alpha$ axonal transport in neuropathic pain. J Peripher Nerv Syst 2011; 16: 277-86.

[36] Berger JV, Deumens R, Goursaud S, et al. Enhanced neuroinflammation and pain hypersensitivity after peripheral nerve injury in rats expressing mutated superoxide dismutase 1 . J Neuroinflammation $2011 ; 8: 33$.

[37] Kim CF, Moalem-Taylor G. Interleukin-17 contributes to neuroinflammation and neuropathic pain following peripheral nerve injury in mice. J Pain 2011; 12: 370-83.

[38] Vallejo R, Tilley DM, Vogel L, et al. The role of glia and the immune system in the development and maintenance of neuropathic pain. Pain Pract 2010; 10: 167-84.

[39] Cady RJ, Glenn JR, Smith KM, et al. Calcitonin Gene-Related Peptide Promotes Cellular Changes in Trigeminal Neurons and Glia Implicated in Peripheral and Central Sensitization. Mol Pain 2011; 6: 94 .

[40] Kadetoff D, Lampa J, Westman M, et al. Evidence of central inflammation in fibromyalgia - Increased cerebrospinal fluid interleukin-8 levels. J Neuroimmunol 2012; 242 (1-2): 33-8.

[41] Clark AK, Staniland AA, Malcangio M. Fractalkine/cx3cr1 signalling in chronic pain and inflammation. Curr Pharm Biotechnol 2011; 12 (10): 1707-14. 
[42] Bao L, Zhu Y, Elhassan AM, et al. Adjuvant-induced arthritis: IL1beta, IL-6 and TNF-alpha are up-regulated in the spinal cord. Neuroreport 2001; 12: 3905-8.

[43] Sun S, Chen WL, Wang PF, et al. Disruption of glial function enhances electroacupuncture analgesia in arthritic rats. Exp Neurol 2006; 198: 294-302.

[44] Sabato AF. Idiopathic Breakthrough Pain: a new hypothesis. Clin Drug Investig 2010; 30(2): 27-9.

[45] Ohara PT, Vit JP, Bhargava A, et al. Gliopathic pain: when satellite glial cells go bad. Neuroscientist 2009; 15: 450-63.

[46] De Leo JA, Tawfik VL, Lacroix-Fralish ML. The tetrapartite synapse: path to CNS sensitization and chronic pain. Pain 2006; 122: 17-21.

[47] Grace PM, Rolan PE, Hutchinson MR. Peripheral immune contributions to the maintenance of central glial activation underlying neuropathic pain. Brain Behav Immun 2011; 25: 1322-32.

[48] Romero-Sandoval EA, Horvath RJ, DeLeo JA. Neuroimmune interactions and pain: focus on glial-modulating targets. Curr Opin Investig Drugs 2008; 9(7): 726-34.

[49] Wieseler-Frank J, Maier SF, Watkins LR. Glial activation and pathological pain. Neurochem Int 2004; 45: 389-95.

[50] Schmid HH. Pathways and mechanisms of N-acylethanolamine biosynthesis: can anandamide be generated selectively? Chem Phys Lipids 2000; 108(1-2): 71-87.

[51] Buznikov GA, Nikitina LA, Bezuglov VV, et al. A putative 'prenervous' endocannabinoid system in early echinoderm development. Dev Neurosci 2010; 32(1): 1-18.

[52] Petrosino S, Iuvone T, Di Marzo V. N-palmitoyl-ethanolamine: Biochemistry and new therapeutic opportunities. Biochimie 2010; 92(6): 724-7.

[53] Kuehl FA Jr, Jacob TA, Ganley OH, et al. The identification of N(2-hydroxyethyl)-palmitamide as a naturally occuring antiinflammatory agent. J Am Chem Soc 1957; 79(19): 5577-8.

[54] D'Argenio G, Petrosino S, Gianfrani C, et al. Overactivity of the intestinal endocannabinoid system in celiac disease and in methotrexate-treated rats. J Mol Med 2007; 85(5): 523-30.

[55] Sarchielli P, Pini LA, Coppola F, et al. Endocannabinoids in chronic migraine: CSF findings suggest a system failure. Neuropsychopharmacology 2007; 32(6): 1384-90.

[56] Darmani NA, Izzo AA, Degenhardt B, et al. Involvement of the cannabimimetic compound, N-palmitoylethanolamine, in inflammatory and neuropathic conditions. A review of the available preclinical data and first human studies. Neuropharmacology 2005; 48(8): 1154-63.

[57] Garcia-Ovejero D, Arevalo-Martin A, Petrosino S, et al. The endocannabinoid system is modulated in response to spinal cord injury in rats. Neurobiol Dis 2009; 33(1): 57-71.

[58] Franklin A, Parmentier-Batteur S, Walter L, et al. Palmitoylethanolamide increases after focal cerebral ischemia and potentiates microglial cell motility. J Neurosci 2003; 23(21): 7767-75.

[59] Loría F, Petrosino S, Mestre L, et al. Study of the regulation of the endocannabinoid system in a virus model of multiple sclerosis reveals a therapeutic effect of palmitoylethanolamide. Eur J Neurosci 2008; 28(4): 633-41.

[60] Re G, Barbero R, Miolo A, et al. Palmitoylethanolamide, endocannabinoids and related cannabimimetic compounds in protection against tissue inflammation and pain: potential use in companion animals. Vet J 2007; 173(1): 21-30.

[61] Rice AS, Farquhar-Smith WP, Nagy I. Endocannabinoids and pain: spinal and peripheral analgesia in inflammation and neuropathy. Prostaglandins Leukot Essent Fatty Acids 2002; 66(2-3): 243-56.

[62] Calignano A, La Rana G, Giuffrida A, et al. Control of pain initiation by endogenous cannabinoids. Nature 1998; 394(6690): 277-81.

[63] Benvenuti F, Lattanzi F, De Gori A, et al. Activity of some derivatives of palmitoylethanolamide on carragenine-induced edema in the rat paw. Boll Soc Ital Biol Sper 1968; 44(9): 809-13.

[64] Jonsson KO, Vandevoorde SV, Lambert DM, et al. Effects of homologues and analogues of palmitoylethanolamide upon the inactivation of the endocannabinoid anandamide. Br J Pharmacol 2001; 133(8): 1263-75.

[65] Calignano A, La Rana G, Piomelli D. Antinociceptive activity of the endogenous fatty acid amide, palmitylethanolamide. Eur J Pharmacol 2001; 419: 191-8.

[66] Mazzari S, Canella R, Petrelli L, et al. N-(2-hydroxyethyl)hexadecanamide is orally active in reducing edema formation and in- flammatory hyperalgesia by down-modulating mast cell activation. Eur J Pharmacol 1996; 300: 227-36.

[67] Xanthos DN, Gaderer S, Drdla R, et al. Central nervous system mast cells in peripheral inflammatory nociception. Mol Pain 2011; 7: 42 .

[68] Leon A, Buriani A, Dal Toso R, et al. Mast cells synthesize, store, and release nerve growth factor. Proc Natl Acad Sci 1994; 91(9): 3739-43.

[69] Nicol GD, Vasko MR. Unraveling the story of NGF-mediated sensitization of nociceptive sensory neurons: ON or OFF the Trks? Mol Interv 2007; 7(1): 26-41.

[70] Michaloudi H, Batzios C, Chiotelli M, et al. Mast cells populations fluctuate along the spinal dura mater of the developing rat. Brain Res 2008; 1226: 8-17.

[71] Biteker M. Current understanding of Kounis syndrome. Exp Rev Clin Immunol 2010; 6(5): 777-88.

[72] Park CS, Bochner BS. Potential targeting of siglecs, mast cell inhibitory receptors, in interstitial cystitis. Int Neurourol J 2011; 15(2): 61-3.

[73] Rudick CN, Pavlov VI, Chen MC, et al. Gender specific pelvic pain severity in neurogenic cystitis. J Urol 2012; 187(2): 715-24.

[74] Oliveira SM, Drewes CC, Silva CR, et al. Involvement of mast cells in a mouse model of postoperative pain. Eur J Pharmacol 2011; 672(1-3): 88-95.

[75] Haidl G, Duan YG, Chen SJ, et al. The role of mast cells in male infertility. Exp Rev Clin Immunol. 2011; 7(5): 627-34.

[76] Klein MM, Lee JW, Siegel SM, et al. Endoneurial pathology of the needlestick-nerve-injury model of Complex Regional Pain Syndrome, including rats with and without pain behaviors. Eur J Pain 2012; 16 (1): 28-37.

[77] Hamilton MJ, Hornick JL, Akin C, et al. Mast cell activation syndrome: a newly recognized disorder with systemic clinical manifestations. J Allergy Clin Immunol 2011; 128(1): 147-52.

[78] Afrin LB. Burning mouth syndrome and mast cell activation disorder. Oral Surg Oral Med Oral Pathol Oral Radiol Endod 2011; 111(4): 465-72.

[79] Ständer S, Raap U, Weisshaar E, et al. Pathogenesis of pruritus. J Dtsch Dermatol Ges 2011; 9(6): 456-63.

[80] Kim DY, Jeoung D, Ro JY. Signaling pathways in the activation of mast cells cocultured with astrocytes and colocalization of both cells in experimental allergic encephalomyelitis. J Immunol 2010; 185(1): 273-83.

[81] Facci L, Dal Toso R, Romanello S, et al. Mast cells express a peripheral cannabinoid receptor with differential sensitivity to anandamide and palmitoylethanolamide. Proc Natl Acad Sci 1995; 92(8): 3376-80.

[82] Cerrato S, Brazis P, Miolo A, et al. Effects of palmitoylethanolamide on immunologically induced histamine, PGD2 and TNF $\alpha$ release from canine skin mast cells. Vet Immunol Immunopathol 2010; 133(1): 9-15.

[83] Cantarella G, Scollo M, Lempereur L, et al. Endocannabinoids inhibit release of nerve growth factor by inflammation-activated mast cells. Biochem Pharmacol 2011; 82(4): 380-8.

[84] Costa B, Colombo A, Bettoni I, et al. The endogenous ligand Palmitoylethanolamide relieves neuropathic pain via mast cell and microglia modulation. Proceedings 21st Annual Symposium of the International Cannabinoid Research Society (ICRS), July 2011, Chicago (USA).

[85] Costa B, Comelli F, Bettoni I, et al. Targeting mast cells in neuropathic pain with the endogenous modulator palmitoylethanolamide. J Peripheral Nerv Syst 2009; 14(Supp11): 10.

[86] De Filippis D, Luongo L, Cipriano M, et al. Palmitoylethanolamide reduces granuloma-induced hyperalgesia by modulation of mast cell activation in rats. Mol Pain 2011; 7: 3 .

[87] Esposito E, Paterniti I, Mazzon E, et al. Effects of palmitoylethanolamide on release of mast cell peptidases and neurotrophic factors after spinal cord injury. Brain Behav Immun 2011; 25(6): 1099112 .

[88] Koch M, Kreutz S, Böttger C, et al. Palmitoylethanolamide protects dentate gyrus granule cells via peroxisome proliferatoractivated receptor- $\alpha$. Neurotox Res $2011 ; 19(2)$ : 330-40.

[89] Muccioli GG, Stella N. Microglia produce and hydrolyze palmitoylethanolamide. Neuropharmacology 2008; 54(1): 16-22.

[90] Redlich S, Ribes S, Schütze S, et al. Palmitoylethanolamide stimulates phagocytosis of Escherichia coli K1 and Streptococcus pneu- 
moniae R6 by microglial cells. J Neuroimmunol 2012 Jan 11. [Epub ahead of print]

[91] Luongo L, Guida F, Gatta L, et al. Palmitoylethanolamide systemic treatment reduces spinal and supraspinal formalin-induced neuroinflammation and allodynia XIV Congress of the European Shock Society. 2011, September, Taormina, Italy.

[92] Lo Verme J, Fu J, Astarita G, et al. The nuclear receptor peroxisome proliferator-activated receptor-alpha mediates the antiinflammatory actions of palmitoylethanolamide. Mol Pharmacol 2005; 67: 15-9

[93] D'Agostino G, La Rana G, Russo R, et al. Acute intracerebroventricular administration of palmitoylethanolamide, an endogenous peroxisome proliferator-activated receptor-alpha agonist, modulates carrageenan-induced paw edema in mice. J Pharmacol Exp Ther 2007; 322(3): 1137-43.

[94] Sasso O, Russo R, Vitiello S, et al. Implication of allopregnanolone in the antinociceptive effect of N-palmitoylethanolamide in acute or persistent pain. Pain 2012; 153(1): 33-41.

[95] Pistis M, Melis M. From surface to nuclear receptors: the endocannabinoid family extends its assets. Curr Med Chem 2010; 17(14): 1450-67.

[96] Ho WS, Barrett DA, Randall MD. Entourage effects of Npalmitoylethanolamide and N-oleoylethanolamide on vasorelaxation to anandamide occur through TRPV1 receptors. Br J Pharmacol 2008; 155 (6): 837-46.

[97] García Mdel C, Adler-Graschinsky E, Celuch SM. Enhancement of the hypotensive effects of intrathecally injected endocannabinoids by the entourage compound palmitoylethanolamide. Eur J Pharmacol 2009; 610(1-3): 75-80.

[98] Lambert DM, DiPaolo FG, Sonveaux P, et al. Analogues and homologues of N-palmitoylethanolamide, a putative endogenous $\mathrm{CB}(2)$ cannabinoid, as potential ligands for the cannabinoid receptors. Biochim Biophys Acta 1999; 1440(2-3): 266-74.

[99] Farquhar-Smith WP, Rice AS. A novel neuroimmune mechanism in cannabinoid-mediated attenuation of nerve growth factorinduced hyperalgesia. Anesthesiology 2003; 99(6): 1391-401.

[100] Di Marzo V. "Direct" and "indirect" endocannabinoids: endogenous biomodulators with protective roles. 1st Symposium on Aliamides in Veterinary Dermatology, March 2012, Verona, Italy.

[101] O'Sullivan SE, Kendall DA. Cannabinoid activation of peroxisome proliferator-activated receptors: potential for modulation of inflammatory disease. Immunobiology 2010; 8: 611-6.

[102] O'Sullivan SE. Cannabinoids go nuclear: evidence for activation of peroxisome proliferator-activated receptors. Br J Pharmacol 2007; $152 ; 576-82$

[103] Godlewski G, Offertáler L, Wagner JA, et al.Receptors for acylethanolamides-GPR55 and GPR119. Prostaglandins Other Lipid Mediat 2009; 89: 105-11.

[104] Carroll CB, Zeissler ML, Hanemann CO, et al. $\Delta(9)$-THC exerts a direct neuroprotective effect in a human cell culture model of Parkinson's disease. Neuropathol Appl Neurobiol 2012 Jan 11. doi: 10.1111/j.1365-2990.2011.01248.x [Epub ahead of print].

[105] Ravingerova T, Adameova A, Carnicka S, et al. The role of PPAR in myocardial response to ischemia in normal and diseased heart. Gen Physiol Biophys 2011; 30(4): 329-41.

[106] Cao Y, Wang Q, Zhou Z, et al. Changes of Peroxisome Proliferator-Activated Receptor- $\gamma$ on Crushed Rat Sciatic Nerves and Differentiated Primary Schwann Cells. J Mol Neurosci 2011 Nov 18. [Epub ahead of print].

[107] Aloe L, Leon A, Levi-Montalcini R. A proposed autacoid mechanism controlling mastocyte behaviour. Agents Actions 1993; 39: C145-7.

[108] De Filippis D, D'Amico A, Iuvone T. Cannabinomimetic control of mast cell mediator release: new perspective in chronic inflammation. J Neuroendocrinol 2008; 20(1): 20-5.

[109] Lau AH, Chow SS. Effects of cannabinoid receptor agonists on immunologically induced histamine release from rat peritoneal mast cells. Eur J Pharmacol 2003; 464(2-3): 229-35.

[110] Nakagawa T, Kaneko S. Spinal astrocytes as therapeutic targets for pathological pain. J Pharmacol Sci 2010; 114: 347-53.

[111] LoVerme J, Russo R, La Rana G, et al. Rapid broad-spectrum analgesia through activation of peroxisome proliferator-activated receptor-alpha. J Pharmacol Exp Ther 2006; 3: 1051-61.

[112] Naccarato M, Pizzuti D, Petrosino S, et al. Possible Anandamide and Palmitoylethanolamide involvement in human stroke. Lipids Health Dis 2010; 9: 47.
[113] Schomacher M, Müller HD, Sommer C, et al. Endocannabinoids mediate neuroprotection after transient focal cerebral ischemia. Brain Res 2008; 1240: 213-20.

[114] Guasti L, Richardson D, Jhaveri M, et al. Minocycline treatment inhibits microglial activation and alters spinal levels of endocannabinoids in a rat model of neuropathic pain. Mol Pain 2009; 5: 35.

[115] Yu HL, Deng XQ, Li YJ, et al. N-palmitoylethanolamide, an endocannabinoid, exhibits antidepressant effects in the forced swim test and the tail suspension test in mice. Pharmacol Rep 2011; 63(3): 834-9.

[116] Scuderi C, Esposito G, Blasio A, et al. Palmitoylethanolamide counteracts reactive astrogliosis induced by $\beta$-amyloid peptide. J Cell Mol Med 2011; 15(12): 2664-74.

[117] Masek K, Perlík F, Klíma J, et al. Prophylactic efficacy of N-2hydroxyethyl palmitamide (impulsin) in acute respiratory tract infections. Eur J Clin Pharmacol 1974; 7: 415-9.

[118] Kahlich R, Klíma J, Cihla F, et al. Studies on prophylactic efficacy of N-2-hydroxyethyl palmitamide (Impulsin) in acute respiratory infections. Serologically controlled field trials. J Hyg Epidemiol Microbiol Immunol 1979; 23: 11-24.

[119] Plesník V, Havrlantová M, Jancová J, et al. Impulsin in the prevention of acute respiratory diseases in school children. Cesk Pediatr 1977; 6: 365-9.

[120] Wiedermannová D, Wiedermann D, Lokaj J. Prophylactic administration of impulsin to clinically healthy children.--effect on the serum proteins and metabolic activity of granulocytes (author's transl). Cas Lek Cesk 1978; 117: 1030-4.

[121] Wiedermannová D, Lokaj J, Wiedermann D. Prophylactic administration of impulsin to clinically healthy children. The effect on $\mathrm{T}$ and B lymphocytes in peripheral blood (author's transl). Cas Lek Cesk 1979; 118: 1249-51.

[122] Keppel Hesselink, JM. Palmitoylethanolamide (Normast): clinical trial overview available at http://www.chronicpaincoalition.com/1/24/502/-normast-clinical-trial-overview-details

[123] G. Guida, A. de Fabiani, F. Lanaia, A. et al. La palmitoiletanolamida (Normast) en el dolor neuropatico cronico por lumbociatalgia de tipo compresivo: estudio clinico multicentrico. Dolor 2010; 25: $35-42$.

[124] Calabrò RS, Gervasi G, Marino S, et al. Misdiagnosed Chronic Pelvic Pain: Pudendal Neuralgia Responding to a Novel Use of Palmitoylethanolamide. Pain Med 2010; 11(5): 781-4.

[125] Schifilliti C, Cucinotta L, Fedele V, et al. Palmitoylethanolamide reduces the symptoms of neuropathic pain in diabetic patients. XIV Congress of the European Shock Society. September, Taormina, Italy 2011.

[126] Bacci C, Cassetta G, Emanuele B, et al. Randomized split-mouth study on postoperative effects of palmitoylethanolamide for impacted lower third molar surgery. ISRN Surg. 20112011917350.

[127] Bortolotti F, Russo M, Bartolucci ML, et al. Palmitoylethanolamide versus NSAID in the treatment of TMJ's pain. J Orofac Pain [in press].

[128] Russo G, Parabita M. Decrease of spasticity and pain after stroke due to treatment with PEA. 14th congress European Shock Soc, Taormina, Italy 2011.

[129] Mancardi GL, Infante MT, Capello E, et al. Palmitoylethanolamide relieves neuropathic pain associated to multiple sclerosis. XL National Congress of the Italian Neurological Society. Padova, Italy 2009.

[130] Phan NQ, Siepmann D, Gralow I, et al. Adjuvant topical therapy with a cannabinoid receptor agonist in facial postherpetic neuralgia. J Dtsch Dermatol Ges 2010; 8: 88-91.

[131] Assini A, Laricchia D, Pizzo R, et al. The carpal tunnel syndrome in diabetes: clinical and electrophysiological improvement after treatment with palmitoylethanolamide Eur J Neurol 2010; 17(S3): 295.

[132] Assini A, Laricchia D, Pizzo R, et al. Tunnel carpale nel paziente diabetico. Migliloramento clinico ed elettrofisiologico dopo trattamento con palmitoiletanolamide. [Carpal tunnel syndrome in the diabetic patient. Clinical and electrophysiologic improvement after treatment with palmitoylethanolamide]. 34th National Congress AISD - New frontiers in pain medicine. May, Riccione, Italy 2011.

[133] Conigliaro R, Drago V, Foster PS, et al. Use of palmitoylethanolamide in the entrapment neuropathy of the median in the wrist. Minerva Med 2011; 102(2): 141-7.

[134] Biasiotta A, Di Stefano G, Leone C, et al. Efficacy of palmitoylethanolamide in patients with painful neuropathy. A clinical and 
neurophysiological open study. Preliminary results. Eur J Pain 2010; 4(1): 77.

[135] Truini A, Biasiotta A, Di Stefano G, et al. Palmitoylethanolamide restores myelinated-fibre function in patients with chemotherapyinduced painful neuropathy. CNS Neurol Disord Drug Targets 2012 Jan 10.

[136] Desio P. Combination of oxycodone and palmitoylethanolamide for low back pain treatment. Rivista Siared di Anestesia e Medicina Critica 2011; 1(2): 62-71.

[137] Desio P. Associazione tra pregabalin e palmitoiletanolamide per il trattamento del dolore neuropatico. [Association of palmitoylethanolamide and pregabalin in the management of neuropathic pain]. Pathos 2010; 17(4): 9-14.

[138] Di Paolo A, Gianfelice V, Silvestri C, et al. La palmitoiletanolamide nel trattamento del dolore attivato dal sistema gliale: nostra esperienza. [Palmitoylethanolamide in the management of gliaactivated pain. Our experience] 34th National Congress AISD New frontiers in pain medicine. May 2011, Riccione, Italy.

[139] Palomba R, Adfiletta S, Candiello A, et al. Multimodal analgesia for chronic pain: rationale and future directions. Naples Pain Conference. Napoli, Italy 2010.

[140] Adiletta S, Candiello A, Arminio D, et al. Pregabalin and Palmitoylethanolamide in diabetic neuropathic pain: an randomized clinical trial. 34th AISD (Italian Association for the Study of Pain) Congress, Riccione, Italy 2011.

[141] Dominguez CM, Diaz Martin AA, Ferrer FG, et al. Palmitoiletanolamida (PEA) en lumbociatica en asociacion al tratamiento habitual. [Palmitoylethanolamide in lumbosciatic pain in association with standard therapy] 8th National Congress of the Sociedad Española del Dolor. May Madrid, Spain 2010.

[142] Canteri L et al. Reduction of analgesics in patients suffering from lumbosciatic pain, treated with palmitoylethanolamide. Dolor 2010; 25: 227-34.

[143] Palomba R, De Simone MG, GIovannini A, et al. Use of palmitotlethanolamide (PEA) + polydatin in the chronic pelvic pain. SIAARTI, October 2010, Parma, Italy.

[144] Fulghesu A, Magnini R, Mazzella S, et al. Treatment of adolescent dysmenorrhea by a new inhibitor of mast cells-induced inflammation (palmitoylethanolamide + trans polydatin). 16th Congress of Pediatric and Adolescent Gynecology, May Montpellier, France 2010.

[145] Indraccolo U, Barbieri F. Effect of palmitoylethanolamidepolydatin combination on chronic pelvic pain associated with endometriosis: preliminary observations. Eur J Obstet Gynecol Reprod Biol 2010; 150(1): 76-9.

[146] Cobellis L, Castaldi MA, Giordano V, et al. Effectiveness of the association micronized N-Palmitoylethanolamine (PEA)transpolydatin in the treatment of chronic pelvic pain related to endometriosis after laparoscopic assessment: a pilot study. Eur J Obstet Gynecol Reprod Biol 2011; 158: 82-6.

[147] Kopsky DJ, Keppel Hesselink JM Nerve regeneration in neuropathic pain. Pain Med 2010; 10: 1576.

[148] Keppel Hesselink JM. Glia as a new target for neuropathic pain, clinical proof of concept for palmitoylethanolamide, a glia modulator. Anesth Pain Intensive Care 2011; 15: 143-5.

\section{(C) Jan M. Keppel Hesselink; Licensee Bentham Open.}

This is an open access article licensed under the terms of the Creative Commons Attribution Non-Commercial License (http://creativecommons.org/licenses/by-nc/3.0/) which permits unrestricted, non-commercial use, distribution and reproduction in any medium, provided the work is properly cited. 